\title{
PENERAPAN PARLIAMENTARY THRESHOLD PADA PEMILIHAN UMUM 2009
}

\author{
Nur'Ayni Itasari \\ Institut Agama Islam Negeri Sunan Ampel, J. A. Yani 1 I 7 Surabaya | \\ judulsj@gmail.com
}

\begin{abstract}
The selection process through the (general) election mechanism can be identified with the electoral system ever implemented in the Islamic government. First, the electoral system of ahl al-hall wa al-'aqd which was carried out by the trust and allegiance. Second, the electoral system of ahl al-hall wa al-aqd which was done through the periodic election, selection in society, and by the head of state. Parliamentary Threshold (PT) is a threshold mechanism in place at legislative elections (for parliament) with a percentage of $2.5 \%$ for the political parties which contested the election to follow the counting in the determination of the House of Representative's seats. Parliamentary Threshold, according to Law No. 10 year 2008, article 202, paragraph I (regarding the election of members of DPR, DPD and DPRD) in the 2009 election, was implemented by calculating the minimum total of $2.5 \%$ of the valid votes in the national political party contestants. Then those parties were listed, which ones were the Parliamentary Threshold and which ones were not the Parliamentary Threshold to determine BPP to calculate the DPR's seats for the electoral party contestants that had passed the threshold.
\end{abstract}

Keywords: Parliamentary threshold, general election, democracy, and constitution.

Abstrak: Proses seleksi melalui mekanisme dalam Pemilu dapat diidentifikasikan dengan sistem pemilihan yang pernah diterapkan dalam pemerintahan Islam. Pertama, sistem pemilihan ahl al-hall wa al'aqd dilakukan berdasarkan kepercayaan dan bai'at. Kedua, sistem pemilihan ahl al-hall wa al-'aqd dilakukan melalui Pemilihan secara berkala, sistem pemilihan ahl al-hall wa al-agd melalui seleksi dalam masyarakat, dan pemilihan ahl al-hall wa al-aqd oleh kepala Negara. Parliamentary Threshold (PT) adalah merupakan mekanisme ambang batas yang diberlakukan pada Pemilu legislatif (khusus DPR) dengan 
prosentase 2,5\% bagi partai politik peserta Pemilu untuk dapat mengikuti penghitungan dalam penentuan perolehan kursi DPR. Parliamentary Threshold menurut pasal 202 ayat (I) UURI No.10/2008 ( tentang Pemilu anggota DPR, DPD, dan DPRD) dalam Pemilu 2009 diterapkan dengan cara menghitung total minimum 2,5\% suara sah secara nasional partai politik peserta Pemilu. Kemudian partai-partai tersebut disusun mana partai PT dan mana partai non PT, baru kemudian dapat ditentukan BPP untuk menghitung perolehan kursi DPR bagi partai peserta Pemilu yang telah lolos ambang batas (PT).

Kata Kunci: Parliamentary threshold, pemilu, demokrasi, dan konstitusional.

\section{Pendahuluan}

Demokrasi sesungguhnya memiliki sejarah panjang sejak bangsa Yunani kuno yang hidup pada tahun 500 SM menemukan dua kata yang teramat populer sepanjang masa, demos (rakyat) dan kratos (pemerintahan) yang melahirkan istilah demokrasi. ${ }^{1}$ Menurut Aristoteles yang dikutip oleh Suyatno dalam bukunya "Menjelajahi Demokrasi", "sebuah konstitusi (politea) barangkali diartikan sebagai sebuah negara kota (polis) yang secara umum memberikan perhatian pada pejabatnya saja, khususnya pada pejabat yang memiliki kedaulatan dalam keseluruhan masalah dalam demokrasi negara kota misalnya, rakyatlah (demos) yang berdaulat ketika rakyat memerintah negara-kota dengan memiliki pandangan terhadap kepentingan umum, bentuk pemerintahannya disebut dengan nama umum pemerintahan yang konstitusional demokrasi sebagai bentuk pemerintahan yang dicurahkan hanya untuk kebaikan kaum miskin." 2

Menurut Philippe C. Schmitter dan Tery Lynn Karl, demokrasi politik modern adalah sistem pemerintahan dimana penguasa mempertanggungjawabkan tindakannya kepada warga

\footnotetext{
I Suyatno,Menjelajahi Demokrasi, (Yogyakarta: Liebe Book Press, 2004), 4

2 lbid., 33-34
} 
negara, bertindak secara langsung melalui kompetisi dan kerjasama den gan wakil-wakil rakyat. ${ }^{3}$

Dalam Islam demokrasi dikenal sebagai substansi bernegara, yaitu suatu hubungan timbal balik antara pemerintah (penguasa atau khalifah) di mana dalam pengambilan keputusan, kesejahteraan rakyat harus dijadikan pertimbangan. Hanya saja dalam Islam pemaknaan demokrasi sebagai kedaulatan rakyat tidak lepas dari kedaulatan Tuhan, yang memiliki otoritas terhadap manusia atas pembuatan dan pelaksanaan suatu aturan hukum.

Dengan kata lain, segala aturan yang dibuat dan yang hendak diterapkan harus berdasarkan al-Qur'an dan Al-Hadits. Demokrasi yang dimaksudkan dalam Islam adalah demokrasi konstitusional, yaitu pemerintahan yang mendasarkan segala hukum dan aturannya pada al-Qur'an dan Al-Hadits dan pemerintahan dengan melibatkan partisipasi rakyat dalam badan legislatif (ahlul halli wal'aqdi), dalam suksesi kepemimpinan, dan juga memberi kebebasan rakyat dalam menyatakan pendapatnya kepada pemimpin (khalifah) hal ini tercermin pada masa kepemimpinan Rasulullah saw. dan khulafaurrasyidin.

Negara yang berkedaulatan rakyat mengandung arti seperti yang dinyatakan oleh Franz Magnis Suseno, bahwa rakyat memiliki "kekuasaan mutlak, tertinggi, tidak terbatas, tidak tergantung, dan tanpa kecuali". Negara dikatakan berkedaulatan rakyat adalah apabila rakyat berperan serta langsung maupun tidak langsung menentukan nasib dan masa depan negara. oleh sebab itu, negara yang berkedaulatan rakyat adalah apabila ada kejelasan tanggung jawab negara terhadap rakyatnya. ${ }^{4}$

Negara-negara yang memiliki wilayah luas seperti Indonesia dan sejalan dengan tuntutan masyarakat dunia, demokrasi hanya dapat terwujud bila ada lembaga-lembaga perwakilan yang berada

\footnotetext{
${ }^{3}$ Ibid., 34

${ }^{4}$ Hendarmin Ranadireksa, Visi Bernegara:Arsitektur Konstitusi Demokratik (Mengapa Ada Negara Yang Gagal Melaksanakan Demokrasi), (Bandung: Fokusmedia, 2007), 55
} 
dalam pengawasan. Karena kebebasan dalam demokrasi berbeda sekali dari kebebasan untuk bertindak tanpa batas. ${ }^{5}$

Oleh karena itu, mewujudkan demokrasi yang demokratis tidak lepas dari sarana-sarana pendukung lahirnya kebebasan hakhak publik yang merupakan kriteria dan tujuan ideologi demokrasi, yakni pemilihan umum untuk menentukan wakilwakil rakyat yang akan duduk di parlemen dengan sarana partai politik.

Partai politik merupakan salah satu sarana dalam merealisasikan partisipasi rakyat baik secara langsung maupun tidak langsung. Dan dalam pembelajaran demokrasi ini, partisipasi rakyat terhadap terwujudnya demokrasi bertujuan untuk membimbing dan membina rakyat demi tercapainya stabilitas yang langgeng. Proses ini diharapkan akan melahirkan rakyat yang melek politik. Selain itu, partai politik juga merupakan sarana berlangsungnya rekrutmen politik, yakni untuk menjaring kaderkader yang siap menjadi generasi penerus bangsa. Dan pembelajaran demokrasi secara langsung melalui partai politik ini secara tidak langsung akan meningkatkan peran serta rakyat dalam mewujudkan komunikasi dan sosialisasi politik yang sehat secara menyeluruh.

Pasca runtuhnya rezim orde baru pada 1998, pencarian jati diri demokrasi yang ideal dalam mewujudkan partisipasi publik semakin digalakkan oleh banyak elemen-elemen yang ada dalam masyarakat. Mulai dari masyarakat sendiri, dengan mendirikan kelompok-kelompok kajian demokrasi yang juga berfungsi sebagai sarana kontrol terhadap pemerintah. Demikian juga dengan pemerintah, banyak kebijakan dan aturan-aturan (UU) yang dibuat dan dihasilkan dengan tujuan mewujudkan demokrasi. Adapun upaya pemerintah diantaranya: pertama, meng-amandemen UUD 1945, yaitu dengan menambah aturan-aturan yang belum jelas, semisal: ditetapkannya sistem pemerintahan menjadi sistem

5 Montesquieu," The Spirit of Law:Dasar-Dasar IImu Hukum dan IImu Politik', penerjemah M.Khoiril Anam, 49 
presidensial (dengan diterapkannya sistem presidensial, demokrasi prosedural akan terlaksana melalui Pemilu sebagai persyaratannya), juga dijaminnya kebebasan berserikat, berkumpul, dan mengeluarkan pendapat (pasal 28 UUD ‘45) yang mewujud pada kebebasan pembentukan partai politik. Kedua, revitalisasi Undang-undang politik, diantaranya: dibuatnya aturan-aturan (UU) Pemilu yang berisikan sistem dan mekanisme Pemilu (UURI No.10/2008), Undang-undang tentang partai politik (UU No.2/2008), dan Undang-undang Pilihan Presiden. Ketiga, menyelenggarakan pemilihan umum sebagai wujud realisasi revitalisasi beberapa Undang-undang politik dengan tujuan menentukan utusan-utusan partai yang akan duduk di kursi parlemen dengan mempertimbangkan kuota kursi, sehingga sistem presidensial yang diharapkan UUD ' 45 terwujud.

Selain itu, reformasi 1998 juga membawa angin segar bagi organisasi-organisasi politik untuk mengambil bagian dalam mewujudkan demokrasi. Proses transisi dari rezim otoritarian menuju demokrasi melalui reformasi belum sempurna secara sistem dan tata cara pemberlakuan demokrasi yang benar-benar mengusung kedaulatan rakyat. Reformasi membawa pengaruh kebebasan di luar batas dimana kebebasan untuk berserikat dan berkumpul ${ }^{6}$ dimaknai sebagai kebebasan tanpa batas, sehingga aturan-aturan (dalam Undang-undang) yang bertujuan untuk menjelaskan secara gamblang hal-hal yang bisa dimaknai secara tersirat dari UUD'45. Sebagaimana yang hendak penulis bahas, tentang diberlakukan UU No. 10 tahun 2008 (tentang Pemilu anggota DPR, DPD, dan DPRD) yang memuat aturan tentang penyederhanaan sistem partai politik melalui perolehan kursi di DPR (Parliamentary Threshold).

Mekanisme ambang batas (Parliamentary Threshold), merupakan wujud bahwa pemerintahan Indonesia terus

\footnotetext{
${ }^{6}$ UUD 1945 pasca amandemen Bab X (warga Negara dan penduduk) pasal 28: "kemerdekaan berserikat dan berkumpul, mengeluarkan pikiran dengan lisan dan tulisan dan sebagainya ditetapkan dalam undang-undang".
} 
berproses mencari sistem demokrasi yang ideal dan fleksibel dengan elemen-elemen pemerintahan yang lain. Selain itu, proses pencarian konsep demokrasi yang ideal ini, sedikit demi sedikit akan mengaktualisasikan pasal 28 UUD'45, bahwa kebebasan yang diberikan tidak selalu dimaknai sebagai kebebasan yang tidak terbatas. Cita-cita yang tertuang dalam pasal 28 UUD'45 tersebut, juga mengandung arti bahwasanya untuk memahami demokrasi sebagai kebebasan memerlukan proses yang panjang.

Sistem Parliamentary Threshold, sebagaimana disebutkan pada paragraf sebelumnya, bertujuan menyederhanakan sistem kepartaian dengan membatasi keaktifan partai politik dengan jumlah perolehan suara untuk dapat mengirimkan wakilnya di parlemen. prosentase yang ditetapkan dalam Parliamentary Threshold sudah tentu memiliki berbagai kekurangan. Sistem tersebut dianggap memotong hak demokrasi partai-partai politik kecil. Karena kemungkinan partai-partai politik kecil untuk bisa mengirim wakilnya ke parlemen semakin kecil. Walaupun demikian, Parliamentary Threshold dianggap mampu menciptakan sistem kepartaian yang sederhana dan sehat sesuai dengan sistem presidensial yang dipakai di Indonesia.

Uraian di atas, menjelaskan bahwa Parliamentary Threshold sebagai salah satu sistem penyederhanaan partai politik, dinilai mampu menjadi sarana proses demokrasi. Dan yang perlu menjadi pertanyaan untuk pembahasan selanjutnya adalah apakah dengan diberlakukannya sistem Parliamentary Threshold pada Pemilu 2009 di Indonesia akan mewujudkan demokrasi konstitusional. Dalam pembahasan selanjutnya, Fiqih Siyasah akan dijadikan pisau analisis terhadap penerapan Parliamentary Threshold pada Pemilu 2009.

\section{Pemilu dalam Fiqh Siyasah}

Dalam pandangan Islam Pemilu merupakan aplikasi konkrit dari sebuah kedaulatan rakyat atas hak-hak politiknya dengan 
berdasar pada konstitusi (al-Qur'an). Yang dalam hal ini menjadi otoritas Allah.

Pemilihan umum sudah menjadi sarana suksesi kepemimpinan yang diterapkan beberapa negara di dunia yang menggunakan sistem pemerintahan demokrasi. Pemilu merupakan salah satu unsur dalam mengukur keberhasilan penerapan konsep demokrasi di suatu negara. Pemilu sebagai aplikasi demokrasi prosedural telah diterapkan. Dalam pemerintahan Islam pada masa khulafaurrasyidin. Secara sederhana Pemilu adalah dikembalikannya hak memilih kepada umat atau rakyat dalam pemilihan para wakilnya yang akan mewakili mereka untuk berbicara atas nama rakyat, menuntut hak-haknya dan membelinya dari hak-haknya yang merugikan mereka. ${ }^{7}$

Suksesi kepemimpinan melalui Pemilu akan membuka pintu demokrasi sebagai satu pembelajaran dan pengalaman dalam suatu negara yang melibatkan partisipasi aktif dari warga negara dan pemerintah (sebagai penyelenggara), juga peserta Pemilu, dalam hal ini, delegasi-delegasi dari partai politik.

Pemilu merupakan aplikasi konkrit dalam demokrasi secara umum atau demokrasi Islam, yang dalam pelaksanaannya dibebankan kepada umat manusia secara keseluruhan atau lebih tepatnya di suatu negara. Namun karena dalam tataran aplikasinya tidak bisa melibatkan seluruh umat secara langsung, maka muncullah dalam konsep fiqih Islam sebuah teori yang disebut An-Niyabah (perwakilan). Istilah ini sebenarnya sudah populer dalam tataran kehidupan mereka secara individu dan mu'amalah yang memerlukan wikalah (perwakilan), kemudian istilah ini muncul dalam tataran hukum, kekuasaan, perwakilan, khilafah, dan lain-lain. ${ }^{8}$

${ }^{7}$ Abdul Karim Zaidan, et.al, Pemilu Dan Parpol Dalam Perspektif Syariah, (Cipta Media, 2003), 34

${ }^{8}$ lbid., 6 
Peran serta umat dalam pemilihan sesungguhnya mengandung permasalahan lain, misalnya: kenapa para fuqaha mengatakan, "barangsiapa yang mendapatkan persetujuan dari kaum muslimin maka ia diangkat menjadi imam atau pemimpin kaum muslimin", jawabnya: karena umat diwajibkan untuk melaksanakan hukum-hukum syari'at, sedangkan pelaksanaannya secara langsung (tanpa sebuah lembaga resmi) tidak memungkinkan. Maka berdasarkan konsep An-Niyabah (perwakilan) dan berdasarkan pandangan bahwa orang yang ingin menegakkan hukum tidak harus dilakukan langsung olehnya, tetapi diwakilkan kepada yang lain. Maka, umat memilih orang tersebut (yang telah mendapatkan persetujuan) untuk menjadi khalifah, atau pemimpin yang akan mewakilinya dalam melaksanakan kewajiban ini. ${ }^{9}$

Dalam melaksanakan kewajibannya seorang imam atau pemimpin memerlukan pihak yang bisa diajak bermusyawarah. Berdasar latar belakang inilah, maka muncul istilah ahlul halli wal'aqdi yaitu segolongan orang yang telah di pilih dan mendapatkan persetujuan dari umat. Dan, persetujuan dari umat hanya dapat diperoleh melalui proses pemilihan dari umat itu sendiri. ${ }^{10}$

\section{Ahl al-Hall wa al-'Aqd}

Ahl al-hall wa al-'aqd adalah sekelompok orang yang memiliki kewenangan untuk memutuskan dan menentukan sesuatu atas nama umat. Dengan kata lain, Ahl al-hall wa al-'aqd adalah lembaga yang menampung dan menyalurkan aspirasi rakyat.

Pada masa-masa awal pemerintahan Islam, yakni pada masa pemerintahan khulafaurrasyidin pemilihan Ahl al-hall wa al-'aqd tidak dilakukan secara prosedural. Hal ini disebabkan masih lekatnya kepercayaan masyarakat kala itu kepada sahabat-sahabat senior. Sehingga banyak sahabat yang kemudian ditokohkan

\footnotetext{
${ }^{9}$ Ibid., 7

${ }^{10}$ lbid.,8
} 
karena kedekatannya dengan Nabi baik dalam perjalanan teologis maupun dalam pertempuran. Sehingga setelah Nabi wafat sahabat-sahabat senior ini menjdi rujukan kepemimpinan baru. Sehingga dapat disimpulkan bahwa kesenioran merupakan proses pemilihan Ahl al-hall wa al-'aqd secara alamiah.

Seiring dengan perkembangan zaman, perluasan wilayah Islam membawa dampak lahirnya imperium baru yakni, imperium yang dibangun orang-orang Islam sebagai legitimasi kekuasaan politik Islam. Dalam proses ini, para ulama Siyasah mulai memandang pentingnya pembentukan lembaga perwakilan rakyat (Ahl al-hall wa al-'aqd). Pembentukan Ahl al-hall wa al-'aqd pertama kali dilakukan pada masa khalifah al-Hakam (961-976 M) pemerintahan Bani Umaiyah di Spanyol. Mereka membentuk majelis syura yang beranggotakan para pembesar negara dan beberapa pemuka masyarakat.

Pada masa modern, pemikiran Barat tentang konsep politiknya mulai mempengaruhi pemikiran para ulama siyasah. Sehingga mereka mengemukakan pentingnya pembentukan lembaga perwakilan rakyat yang nantinya bisa merepresentasikan kehendak rakyat. Dalam prakteknya, al-Anshari seperti dikutip oleh M.Iqbal, mengemukakan mekanisme pemilihan anggota $\mathrm{Ahl}$ al-hall wa al-'aqd melalui beberapa cara, yaitu:

a. Pemilihan umum dilakukan secara berkala, dalam sistem pemilihan ini anggota masyarakat yang telah memenuhi persyaratan memilih anggota Ahl al-hall wa al-'aqd sesuai dengan pilihannya.

b. Pemilihan Ahl al-hall wa al-'aqd melalui seleksi dalam masyarakat. Dalam hal ini, masyarakat akan melihat orangorang yang mempunyai integritas dan perhatian yang besar kepada umat.

c. Pemilihan anggota Ahl al-hall wa al-'aqd oleh kepala negara.

Ahl al-hall wa al-'aqd mempunyai tugas sebagaimana tugas lembaga legislatif yaitu legislasi. Akan tetapi legislasi yang dijalankan pemerintahan Islam berbeda dengan legislasi yang 
dijalankan pemerintahan demokrasi. Dalam pemerintahan Islam, legislasi harus didasarkan pada al-Qur'an dan al-Hadits sebagai konstitusi tertinggi. Akan tetapi, manakala terdapat masalah yang belum atau tidak tercakup dalam al-Qur'an dan al-Hadits, maka Ahl al-hall wa al-'aqd bisa melakukan ijtihad kolektif untuk menentukan aturan-aturan baru. Dan hal inipun, harus tetap dilakukan dengan tanpa meninggalkan al-Qur'an. Dalam artian ijtihad dilakukan dengan konsep qiyas (analogi).

\section{Bai'at}

Jika dalam negara dengan bentuk pemerintahan demokrasi menggunakan saran Pemilu untuk memilih wakil-wakil rakyat. Maka, dalam negara Islam terdapat sistem bai'at yang di dalamnya tidak hanya mengandung makna Pemilu tetapi juga kontrak sosial.

Bai'at berasal dari kata $b a^{\prime} a$ (menjual) yang mengandung makna perjanjian. Dalam pelaksanaan bai'at selalu melibatkan dua pihak, rakyat dan pemerintah. Adapun bai'at secara istilah adalah ungkapan perjanjian antara pemerintah dan rakyatnya untuk menyerahkan dirinya dan kesetiaan nya secara ikhlas dan secara timbal balik.

Implementasi bai'at dalam hak dan kewajiban secara timbal balik inilah yang mengandung dua pekerjaan, yaitu pemilihan umum (wujud pola kepercayaan rakyat kepada pemimpinnya) dan kontrak sosial, yang merupakan perjanjian timbal balik. Sebagai konsekuensi kepercayaan yang diberikan oleh rakyatnya.

Fiqh Siyasah terhadap Penerapan Parliamentary Threshold Pada Pemilu 2009 di Indonesia

Suatu Negara dalam sistem pemerintahan demokrasi akan membuka peluang bagi seluruh warga negaranya untuk berpartisipasi dalam setiap pengambilan kebijakan baik secara langsung maupun tidak langsung (perwakilan). Dalam sistem demokrasi langsung penyertaan masyarakat dalam setiap pengambilan kebijakan biasanya menggunakan pola referendum 
(jajak pendapat), yang mana pola ini mudah diterapkan pada negara dengan wilayah kecil. Akan berbeda hasilnya manakala pola referendum coba diterapkan di satu Negara dengan wilayah luas seperti Indonesia. Sehingga untuk mengambil suatu keputusan dengan melibatkan partisipasi seluruh warga Negara tidak harus dengan melempar permasalahan dan pengambilan kebijakan ke wilayah publik. Karena pola perwakilan lebih efektif dan efisien untuk produk demokrasi.

Demokrasi perwakilan membutuhkan banyak sarana sebagai konduktor ide dari masyarakat kepada pemimpinnya, seperti parlemen (DPR, DPD, dan DPRD) dan Pemilu. Pemilu merupakan salah satu ajang kompetisi dan penjaringan pejabat-pejabat publik yang merupakan kader-kader partai politik. Meskipun belum seratus persen Pemilu dan partai politik mewadahi partisipasi dan kepentingan masyarakat, tetapi paling tidak partai politik dan Pemilu telah merepresentasikan demokrasi prosedural. Karena untuk mencapai ideology demokrasi yang sesungguhnya memerlukan proses. Melalui proses inilah pencerdasan dan pendewasaan politik publik akan terwujud.

Demokrasi perwakilan yang saat ini diterapkan di Indonesia dengan padanan sistem presidensial, sebagai manifestasi pengaruh presiden terhadap pengambilan dan pelaksanaan kebijakan (UUD'45 pasca amandemen). Dalam sistem ini, presiden tidak bertanggung jawab kepada parlemen. Bahkan presiden bisa mengajukan usulan terhadap suatu RUU yang sedang dikerjakan oleh lembaga dewan. Di samping sistem presidensial, juga diterapkan sistem multi partai sebagai sistem kepartaian saat ini.

Sebagaimana kita tahu, bahwa untuk mewujudkan sistem presidensial yang kuat diperlukan partai politik pendukung yang kuat. Untuk itulah diperlukan satu sistem penjaring partai-partai politik peserta Pemilu yang semakin menjamur akibat sistem kepartaian multi partai.

Dengan tujuan menciptakan sistem multi partai sederhana, konsep Parliamentary Threshold atau konsep ambang batas (pasal 
202 ayat ' 1 ' UURI No.10/2008 (tentang Pemilu anggota DPR, DPD, dan DPRD) yang memuat aturan ambang batas 2,5\% bagi partai politik peserta Pemilu untuk mengirimkan kadernya di parlemen atau lebih tepatnya Parliamentary Threshold merupakan mekanisme ambang batas bagi partai politik peserta Pemilu untuk diikutkan pada penghitungan suara di DPR pusat dengan patokan jumlah suara sah secara nasional dikali 2,5\%). Pola ambang batas untuk menekan proporsi partai politik di parlemen sebelumnya telah banyak diterapkan di Negara-negara lain seperti Jerman, Turki dan lain-lain dengan besaran prosentase yang berbeda (misal di Indonesia dengan 2,5\%).

UUD'45 pasca amandemen melahirkan beberapa aturan baru bagi sistem politik di Indonesia. Seperti sistem presidensial dan sistem multi partai, serta sistem Pemilu dengan aturan-aturan pelaksana dalam UU Pemilu. Ketiga sistem politik ini memiliki keterkaitan satu sama lain. Seperti, sistem presidensial akan menjadi sistem pemerintahan yang efektif manakala sistem kepartaian yang ada mendukung. Oleh karena itu, untuk menyeimbangkan satu aturan politik dengan aturan lainnya diperlukan aturan-aturan yang mampu me-manage-nya. Seperti dalam bahasan karya tulis ini, bahwa untuk memaksimalisasikan kinerja presiden sebagai pemegang tongkat presidensial diperlukan aturan-aturan yang jelas dalam Pemilu legislatif, yakni dengan menerapkan mekanisme ambang batas sebagaimana disebut sebelumnya.

Penerapan Parliamentary Threshold akan memunculkan dampak politis yang menyehatkan demokrasi, meskipun tidak secara keseluruhan. Hal ini bisa dilihat, manakala mekanisme ambang batas ini diterapkan, partai-partai yang mampu melampauinya akan terdorong untuk meningkatkan kinerjanya di parlemen, karena hal ini akan menjadi bahasan evaluasi publik untuk Pemilu berikutnya, karena ada kemungkinan besaran threshold dinaikkan. Bagi partai-partai yang tidak bisa melampauinya akan terdorong untuk membangun koalisi dengan 
partai lain, koalisi ini akan melahirkan dua kekuatan, yaitu: pertama, kekuatan koalisi pendukung presiden, dan kedua, koalisi menjadi kekuatan oposisi yang akan terus mengevaluasi kinerja presiden.

Sistem presidensial dan sistem multi partai berjalan dengan jaminan konstitusional. Penerapan ambang batas dibuat sedemikian rupa dengan konsekuensi dan reward bagi masingmasing pihak dengan tanpa menciderai konstitusi. Asas-asas konstitusi tetap dijunjung dengan perimbangan-perimbangan dalam aturan-aturan selanjutnya.

Prinsip-prinsip konstitusional yang terdapat dalam aturanaturan (UU) sejalan dengan prinsip-prinsip konstitusional dalam teori politik Islam. Dalam Negara Islam setiap pembuatan keputusan yang berhubungan dengan kebijakan publik harus berlandaskan pada konstitusi (al-Qur'an), sebagaimana asas kedaulatan yang ada dalam Islam, yaitu asas kedaulatan Tuhan yang merupakan hak mutlak-Nya yang secara yuridis terwujud berupa al-Qur'an dan secara defakto berupa alam, sebagaimana firman Allah sebagai berikut:

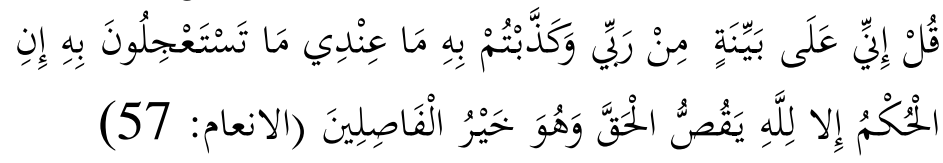

Artinya: "Katakanlah: sesungguhnya aku (berada) di atas hujjah yang nyata (al-Qur'an) dari Tuhanku sedang kamu mendustakannya. Bukanlah wewenangku (untuk menurunkan azab) yang kamu tuntut untuk disegerakan kedatangannya. Menetapkan hukum itu hanyalah hak Allah, Dia menerangkan yang sebenarnya dan Dia pemberi keputusan yang paling baik" (QS AlAn'Am (6):57) ${ }^{11}$

" DEPAG RI, al-Qur'an dan Terjemahnya, 195 
Dari sisi kedaulatan, demokrasi dan konsep pemerintahan Islam memang berbeda. Demokrasi adalah sistem pemerintahan yang memposisikan rakyat sebagai pemegang kedaulatan, sehingga aturan-aturan (UU) dibuat berdasarkan kehendak rakyat. Sedang dalam pemerintahan Islam, kedaulatan adalah hak mutlak Allah. Dimana, hal kedaulatan ini terkait dengan konstitusi yang digunakan dalam suatu Negara Islam (al-Qur'an) dan segala peraturan yang dibuat haruslah berdasarkan pada al-Qur'an.

Konsep kedaulatan dalam Islam melahirkan konsep pemerintahan khilafah, yang merupakan representasi perwakilan Tuhan di bumi. Demikian disebutkan Allah dalam firman-Nya:

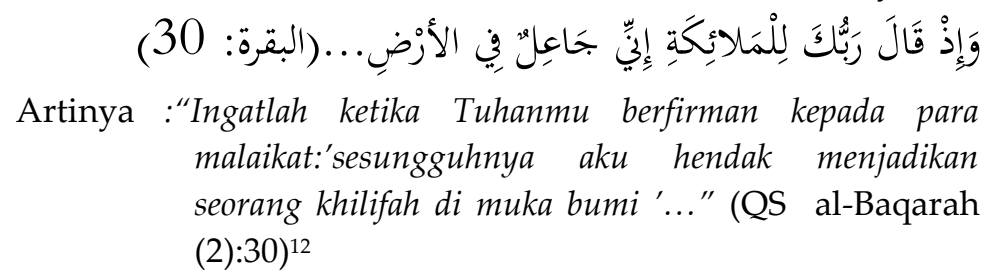

Dari sini sistem pemerintahan dalam Negara Islam ditarik ke wilayah otokrasi. Akantetapi otokrasi dalam Islam berbeda dengan otokrasi yang pernah berlangsung di Eropa (otokrasi dengan dominasi pendeta yang menggunakan agama sebagai legitimasi keabsahan atas kekuasaan mereka). Menurut Abul A'la AlMaududi $^{13}$ teokrasi yang dibangun berdasarkan Islam tidak ditempatkan di bawah kekuasaan kelas agama tertentu melainkan di tangan seluruh masyarakat muslim. Kaum muslimin secara keseluruhan menjalankan roda pemerintahan sesuai dengan petunjuk-petunjuk Allah dalam al-Qur'an dan as-Sunnah (aturanaturan pelaksanaan yang dijalankan oleh Nabi).

Di samping kekhalifahan yang merupakan manifestasi kedaulatan Tuhan di muka bumi, dalam Islam juga dikenal konsep

\footnotetext{
${ }^{12}$ Ibid., 13

${ }^{13}$ Abul A'la Al-Maududi, The Islamic Law And Constitution, penerjemah Asep Hikmat, Hukum dan Konstitusi: Sistem Politik Islam, (Bandung: Mizan, 1995), I 59
} 
kedaulatan rakyat yang merupakan kekuasaan yang telah dijanjikan Allah untuk manusia. Dalam al-Qur'an Allah menyebutkan bahwa kekuasaan untuk memerintah bumi telah dijanjikan kepada seluruh masyarakat mukmin dengan tanpa membedakan dari etnis, kelompok dan keluarga manapun. Dari sini dapat disimpulkan bahwa semua kaum beriman merupakan penjelmaan dari kekhalifahan. Kekhalifahan yang dianugerahan Allah kepada orang-orang muslim merupakan kekhalifahan umum dan bukan kekhalifahan terbatas. ${ }^{14}$

Konsep kedaulatan Tuhan dan kedaulatan rakyat yang terwujud dalam konsep khalifah ini disimpulkan oleh Maududi dengan membuat formulasi konsep demokrasi dalam Islam, yaitu sistem pemerintahan "teo-demokrasi (demokrasi Ilahi)", dengan sistem pemerintahan ini kaum muslimin diberi kedaulatan rakyat secara terbatas di bawah kedaulatan Allah. Jadi, khalifah atau eksekutif menurut sistem pemerintahan ini terikat oleh keinginan kaum muslimin pada umumnya. ${ }^{15}$

Sementara itu, legislatif dalam pemerintahan Islam disebut sebagai lembaga penengah dan pemberi fatwa (ahl al-hall wa al'aqd) - adapun pemilihan secara langsung untuk memilih siapa-siapa yang menjadi anggota dewan (ahl al-hall wa al-'aqd) belum terorganisir. Orang-orang yang bisa duduk dalam dewan ini adalah para sahabat yang ditokohkan berdasarkan keseniorannya sebagai pendahulu dalam memeluk Islam dan menjadi sahabat Nabi. Para sahabat senior ini menjadi rujukan kepemimpinan baru pasca wafatnya Nabi, karena mereka dianggap mampu secara politik maupun agama. Adapun proses pemilihannya bukan dengan cara pemungutan suara (Pemilu) melainkan melalui ujian praktek dan pelaksana kerja. Jadi sistem pemilihan lembaga legislatif dalam Islam didasari kepercayaan kaum muslimin sepanjang mereka memperoleh kepercayaan Rasul sendiri. ${ }^{16}$

\footnotetext{
14 Ibid., 169

15 Ibid., 160

${ }^{16} \mathrm{lbid}$.
} 
Penokohan sebagai sahabat senior yang dianggap dekat dengan Nabi pada masa awal Islam menjadi sistem jarring seleksi anggota dewan (ahl al-hall wa a-aqd) yang nantinya berfungsi sebagai dewan yang menentukan pemilihan dan pengangkatan seorang khalifah dan menjadi badan konsultasi pemerintah. Jika hal ini di tarik dalam realitas Pemilu legislatif di Indonesia saat ini maka, dapat disimpulkan bahwa untuk memperoleh jabatan wakil rakyat haruslah melalui proses penempatan diri dalam mata masyarakat. Dari proses inilah akan lahir kepercayaan masyarakat terhadap mereka.

Sebagaimana telah dijelaskan oleh penulis pada pokok bahasan sebelumnya, parliamentary threshold merupakan mekanisme ambang batas untuk menyeleksi partai-partai mana yang bisa mengikuti penentuan perolehan kursi DPR dengan tanpa menodai amanat konstitusi (UUD 1945).

Jika dalam sistem pemerintahan modern (demokrasi) dengan trias politiknya. Badan perwakilan rakyat disebut sebagai badan legislatif, dalam Islam disebut Ahl al-hall wa al-'aqd yang dalam pemilihannya telah mengalami beberapa fase, yaitu: pertama, pada masa awal pemerintahan Islam, pemilihan Ahl al-hall wa al-'aqd belum terorganisir secara prosedural melainkan dengan melalui seleksi alamiah. Yakni berdasarkan pada kepercayaan masyarakat muslim terhadap kesenioran sahabat-sahabat yang secara alamiah menjadi rujukan kepemimpinan baru setelah wafatnya Nabi Saw.

Seiring dengan berkembangnya pemerintahan Islam, sistem pemilihan Ahl al-hall wa al-'aqd memasuki fase kedua. Pada masa ini pengaruh pemikiran Barat tentang sistem politiknya telah mempengaruhi pemikiran para ulama siyasah tentang pentingnya pembentukan Ahl al-hall wa al-'aqd secara prosedural. Al-Anshari berpendapat, bahwa pembentukaanggota Ahl al-hall wa al-'aqd harus melalui ${ }^{17}$ :

17 Muhammad Iqbal, Fiqh Siyasah Kontekstualisasi Doktrin Politik Islam, (Jakarta: Gaya Media Pratama, 200 I), 143 
1. Pemilihan umum dilakukan secara berkala, dalam sistem pemilihan ini anggota masyarakat yang telah memenuhi persyaratan memilih anggota Ahl al-hall wa al-'aqd sesuai dengan pilihannya.

2. Pemilihan Ahl al-hall wa al-'aqd melalui seleksi dalam masyarakat. Dalam hal ini, masyarakat akan melihat orangorang yang mempunyai integritas dan perhatian yang besar kepada umat.

3. Pemilihan anggota Ahl al-hall wa al-'aqd oleh kepala negara.

Jika dipadankan pada tujuan parliamentary threshold untuk menyederhanakan sistem multi partai melalui proses seleksi dengan ambang batas. Maka perpaduan sistem pemilihan ahl al-hall wa al'aqd dengan menjalankan Pemilu secara berkala dengan memberi kebebasan pada masyarakat muslim sebagai konstituen (sistem I) dan dengan melakukan seleksi anggota ahl al-hall wa al-'aqd pada Pemilu.

Seleksi pemilihan anggota ahl al-hall wa al-'aqd yang dilaksanakan secara berkala dengan memberikan kebebasan kepada masyarakat untuk memilih. Tentunya dengan tujuan mengoptimalkan kinerja lembaga permusyawaratan dan demi menjaga terwujudnya hubungan hak dan kewajiban secara timbal balik. Karena dalam Pemilu di negara Islam ada bai'at yang mengandung dua unsur, yakni pemilihan yang memberikan kebebasan kepada rakyat untuk mengimplementasikan kedaulatannya untuk merepresentasikan kepentingan dan dalam bai'at juga terkandung makna "kontrak sosial", yang mana mengikat hak dan kewajiban para wakil rakyat dengan rakyatnya.

\section{Penutup}

1. Dalam Fiqh Siyasah pemilihan anggota ahl al-hall wa al-'aqd dapat dilakukan dengan dua sistem, yaitu:

a. Pemilihan anggota ahl al-hall wa al-'aqd secara alamiah. Pemilihan dengan sistem ini diterapkan pada masa khulafaurrasyidin dengan alasan kesenioran sahabat- 
sahabat yang diukur dari kedekatannya dengan Nabi, sehingga setelah wafatnya Nabi, sahabat-sahabat ini menjadi rujukan kepemimpinan baru.

b. Pemilihan ahl al-hall wa al-'aqd melalui Pemilu secara prosedural, yaitu: dengan melaksanakan Pemilu secara berkala dengan memberikan kebebasan kepada rakyat untuk memilih wakilnya, pemilihan anggota ahl al-hall wa al'aqd melalui seleksi dalam masyarakat, dan pemilihan anggota ahl al-hall wa al-'aqd oleh kepala negara.

2. Parliamentary Threshold adalah merupakan mekanisme ambang batas yang diberlakukan pada Pemilu legislatif (khusus DPR) dengan prosentase $2,5 \%$ bagi partai politik peserta Pemilu untuk dapat mengikuti penghitungan dalam penentuan perolehan kursi DPR. Parliamentary Threshold menurut pasal 202 ayat (1) UURI No.10/2008 (tentang Pemilu anggota DPR, DPD, dan DPRD) dalam Pemilu 2009 diterapkan dengan cara menghitung total minimum 2,5\% suara sah secara nasional partai politik peserta Pemilu. Kemudian partai-partai tersebut disusun mana partai PT dan mana partai non PT, baru kemudian dapat ditentukan BPP untuk menghitung perolehan kursi DPR bagi partai peserta Pemilu yang telah lolos ambang batas (PT).

3. Parliamentary threshold yang merupakan mekanisme ambang batas dalam Pemilu legislatif memiliki persamaan dengan mekanisme pemilihan anggota ahl al-hall wa al-'aqd, yakni untuk melakukan seleksi terhadap anggota perwakilan rakyat. Hanya saja secara prosedural berbeda, di mana dalam parliamentary threshold ada prosentase 2,5\% untuk melakukan penghitungan suara partai politik peserta Pemilu secara nasional. Selain itu, kedua sistem Pemilu tersebut, memiliki visi yang sama yakni mewujudkan sebuah pemerintahan yang konstitusional. 


\section{Daftar Pustaka}

Zaidan, Abdul Karim, et al. Pemilu dan Parpol Dalam Perspektif Syari'ah. Cipta Media, 2003

Ranadireksa, Hendarmin. Visi Bernegara: Arsitektur Konstitusi Demokratik (Mengapa Ada Negara Yang Gagal Melaksanakan Demokrasi). Bandung: Fokusmedia, 2007

Maududi (al-), Abul A'la. The Islamic Law And Constitution. alih bahasa Asep Hikmat. Hukum dan Konstitusi: Sistem Politik Islam. Bandung: Mizan, 1995

Iqbal, Muhammad. Figh Siyasah Kontekstualisasi Doktrin Politik Islam. Jakarta: Gaya Media Pratama, 2001

Suyatno. Menjelajahi Demokrasi. Yogyakarta: Liebe Book Press, 2004 DEPAG RI, al-Qur'an dan Terjemahnya. Jakarta: PT. Arga Printing, 2008

Montesquieu. The Spirit of Law: Dasar-Dasar Ilmu Hukum dan Ilmu Politik". penerjemah M.Khoiril Anam. 